\title{
ОСНОВИ РАЦІОНАЛЬНОГО ХАРЧУВАННЯ СТУДЕНТІВ
}

\author{
C. I. Чернецька
}

Кіровоградський медичний коледж

Важливою складовою здорового способу життя є раціональне харчування, яке допомагає підтримувати високий рівень життедіяльності. У статті проаналізовано основні елементи харчування, необхідні для нормального функціонування організму.

\section{ESSENTIALS OF STUDENTS' BALANCED NUTRITION}

\author{
S. I. Chernetska
}

Kirovohrad Medical College

An important part of a healthy lifestyle is a balanced diet that helps to maintain a high level of personal activity. The article analyzes the main nutrients needed for normal body functioning.

Вступ. Підтримання високого рівня працездатності, успішна адаптація до умов навчання у вузі залежать від стану здоров' я людини. Найголовніший шлях - це формування здорового способу життя, який передбачає дотримання певних правил, спрямованих на підтримку і розвиток високого рівня життєдіяльності й ґрунтується на оптимальному поєднанні праці та відпочинку, раціональному харчуванні, утриманні від шкідливих звичок, руховому режимі, вмінні застосовувати засоби відновлення [1,2].

Особливу увагу привертає стан здоров'я та умови харчування молоді, оскільки $\epsilon$ умовою створення міцного суспільства.

Науковим обґрунтуванням ефективного використання харчування як фактора збереження здоров'я людини і профрілактики захворювань $\epsilon$ теоретичний розгляд взаємозв'язку харчування та життєдіяльності організму [3].

Сучасні наукові теорії харчування розробляють численні вітчизняні (М. П. Гуліч, О. М. Григоренко, А. Ф. Доронін, А. І. Жаринов, Л. В. Капрельянц, А. Г. Кльонова, А. А. Покровський, В. І. Смоляр, А. М. Угольов, Л. Ф. Щелкунов) і закордонні (Д. С. Джарвис, К. Монастирський, А. Робертсон, Г. Шелтон) науковці $[2,3,4,6]$.

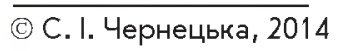

Одним з найважливіших факторів зовнішнього середовища єїжа, яка бере участь у всіх життєвих процесах. Харчування - це засіб підтримки життя, росту, розвитку і працездатності людини. А раціональним є таке харчування, яке відповідає потребам організму і виробленим ним енергетичним витратам. Основним принципом раціонального харчування $є$ його збалансованість і правильний режим. Для правильної організації харчування необхідно визначити значення для людини окремих харчових речовин і виразно уявляти собі потребу в них залежно від віку, професії, клімату і соціально-побутових умов $[2,5]$.

Основна частина. Для нормального функціонування організму необхідно сім основних елементів харчування. Тривала відсутність навіть одного з них може призвести до негативних порушень у здоров'ї $[1,6]$. Розташуємо їх за важливістю для організму:

Вода. За різними теоріями, на добу організм потребує від 1,5 до 3 літрів води. Не забувайте, ми в основному складаємося з води, тому для нормальної життєдіяльності нам необхідно споживати багато води.

Білок - основний «будівельний матеріал» нашого організму. Риба, курятина або індичка без шкіри, сухі боби та горох містять найбільше білка і 
не багато жиру. Корисними для споживання $є$ такі продукти: яловичина, свинина, баранина.

Вуглеводи - основне «паливо» для нормальної життєдіяльності. Організм не накопичує вуглеводи. Хліб, каші та макаронні вироби містять цілий комплекс вуглеводів (а це важливе джерело енергіi), вітамінів, мінералів і рослинних волокон. Вважають, що крохмалевмісні продукти сприяють збільшенню маси тіла людини. Проте небезпека не в них, а в звичайних для цих страв добавках, що містять велику кількість жиру: вершковому маслі на бутерброді, підливі до макаронів. Не споживайте їжу, яка містить багато вершкового масла і цукру, а значить, і надлишок легкозасвоюваних вуглеводів - булочок і тістечок. У раціоні має бути хліб з висівками, який містить корисні рослинні волокна.

Жири-дуже важливий елемент у нашому харчуванні. Вони виконують функцію акумуляції енергіi. Харчування не буде здоровим без певної кількості жиру. Водночас всі жири в їжі - це суміш трьох типів жирних кислот: насичених, мононенасичених і поліненасичених. Насичені жири є в м'ясі та молочних продуктах, кокосі, пальмовій оліі. Його потрібно обмежити до $10 \%$ калорій (що складає приблизно третину споживаного жиру) або менше. Перевищення цієі межі сприяє підвищенню холестерину в крові та збільшує ризик виникнення серцевих захворювань. Мононенасичені жири (в оливковій і арахісовій олії) і поліненасичені жири (головним чином в овочах, кукурудзі, сої та в деяких сортах риби) є значно кориснішими.

Клітковину безпосередньо організм не засвоює і в обмінних процесах не бере участь, але виконує життєво важливі функції в організмі, зокрема покращує травлення, нормалізує випорожнення. Рекомендується споживати 3040 грамів клітковини на день.

Вітаміни. Мікроелементи. Вітаміни і мікроелементи - це низькомолекулярні органічні сполуки різної хімічної природи, які необхідні для життєдіяльності живого організму в малих дозах, іне утворюються в самому організмі в достатній кількості, через що повинні надходити із їжею. Вони не виконують в організмі ані енергетичної, ні структурної функції, але $є$ необхідними для використання тих сполук, які ці функції виконують, зокрема білків, ліпідів та вуглеводів.

Світова статистика стверджує, що 70 \% смертей відбуваються з трьох основних причин: серцевосудинні захворювання, ракові захворювання, інсульти. 50 \% причин, що викликають ці захворювання, безпосередньо пов'язані з харчуванням. У нашому звичайному харчуванні є надлишок речовин, шкідливих для нашого організму, а з іншого боку, нам не вистачає багатьох необхідних поживних речовин (табл. 1).

\section{Таблиця 1. Надлишкові та дефіцитні елементи харчування сучасних людей}

\begin{tabular}{|l|l|}
\hline \multicolumn{1}{|c|}{ НАДЛИШОК } & \multicolumn{1}{c|}{ НЕСТАЧА } \\
\hline Білки тваринного походження (м'ясо) & Вітаміни \\
\hline Жири & Мінерали \\
\hline Вуглеводи & Білки, незамінні амінокислоти \\
\hline Сіль & Рослинна клітковина \\
\hline Цукор & Вода \\
\hline $\begin{array}{l}\text { Канцерогени (речовини, які утворюються при приготуванні іжі - } \\
\text { смаженні, копченні - консерванти, добрива, пестициди тощо) }\end{array}$ & Поліненасичені жирні кислоти \\
\hline
\end{tabular}

Багаторічною практикою вироблено такі правила раціонального харчування.

1. Свіжоїдіння. Здавна вважали, що в сирих рослинних продуктах міститься найбільша цілюща сила, апродукти, які вже пролежали довго іпідсохли є менш цінними. Не можна залишати приготовлену їжу навіть на кілька годин. У ній починаються процеси бродіння і гниття. Тому з'їдати необхідно відразу ж.

2. Різноманітність їжі: чим більше різних продуктів включено в раціон, тим більше фізіологічно активних речовин надходить в організм. При розумовому навантаженні потреба в них збільшується, а апетит часто знижений. 
3. Певне чергування продуктів. Воно випливає 3 попереднього і вказує на те, що не можна довго вживати один продукт.

4. Сезонність харчування. Навесні та влітку потрібно збільшити кількість рослинної їі. У холодну пору необхідно додати в раціон продукти, багаті на білки і жири.

5. Максимум задоволення від їжі. Для цього, перш за все, потрібно відмовитися від поспіху, хоча 6 на час вживання їжі. Необхідно, крім того, назавжди відмовитися від звички з'ясовувати стосунки під час споживання їжі, а також читати.

6. Певне поєднання продуктів. $Є$ несумісні страви, і це обов'язково потрібно враховувати. При неправильному харчовому поєднанні у кишечнику виникають процеси бродіння і гниття їжі, відбувається отруєння утвореними шкідливими речовинами.

\section{ЛІТЕРАТУРА}

1. КоньшевВ. Критерийправильногопитания [Текст] / В. Конышев / / Физкультура и спорт. - 2013. - № 1. C. 10-11.

2. Горчаков В. Харчування, що гармонізує, - міф чи реальність? / В. Горчаков, Л. Горчакова / / Науковий світ. - 2008. - № 9. - С. 12-13.

3. Маркова А. Принципрационального питания [Текст]: он позволяет сохранить здоровье / А. Маркова // Спортивная жизнь России. - 2002. - № 8. - С. 21-22.
7. Уникання дієтичних стресів (різких змін режиму харчування, що викликають значне напруження адаптаційних механізмів), тобто не рекомендується один день нічого не їсти, а в інший переїдати.

Висновки. Підсумовуючи вищесказане, можна стверджувати, що раціональне харчування це фізіологічно повноцінне харчування здорових людей із врахуванням їх віку, статі, характеру праці та інших чинників. Раціональне харчування студентів сприяє збереженню здоров'я, опірності шкідливим факторам навколишнього середовища, високій фізичній й розумовій працездатності, а також активному довголіттю. При раціональному харчуванні потрібно дотримуватись: 1) харчового раціону; 2) режиму харчування; 3) умов вживання їжі.

4. Мороз Т. Правда о рациональном питании / Т. Мороз / / Секретарь-референт. - 2008. - № 11 . C. $80-84$.

5. Рациональное питание [Текст] : тест источников бесперебойного питания // СНIP. - 2006. - № 8. с. 54-57.

6. Шам А. Л. Раціональне харчування - запоруказдоров'я. Дидактичний матеріал / А. Л. Шам / / Біологія. -2008 . - № 16-18. - С. 33-34. 